\title{
IMPLEMENTASI PELAYANAN KESEHATAN \\ MENURUT UNDANG-UNDANG NO. 24 TAHUN 2011 \\ TENTANG BADAN PENYELENGGARA JAMINAN SOSIAL (BPJS) \\ (Studi di RSUD Kertosono Kabupaten Nganjuk)
}

\author{
-Binar Idha Meutia-
}

\begin{abstract}
ABSTRAK
Tujuan penelitian ini ialah untuk menganalisis pelayanan kesehatan BPJS Kesehatan di RSUD Kertosono Kabupaten Nganjuk, dan untuk menganalisis faktor-faktor pendukung dan penghambat dari pelayanan kesehatan BPJS Kesehatan di RSUD Kertosono Kabupaten Nganjuk. Adapun hasil dari penelitian ini ialah: Pertama, Pelayanan kesehatan di RSUD Kertosono Kabupaten Nganjuk dikatakan sangat baik, hal tersebut dikarenakan komitmen dari RSUD Kertosono yang ingin memberikan pelayanan kesehatan sesuai dengan standar yang baik dan berdasarkan standar pelayanan publik kepada masyarakat. Kedua, Faktor pendukung dalam memberi layanan kepada pasien ialah, sikap pegawai yang ramah dan sopan santun, pelayanan yang diberikan memuaskan dan alur yang mudah, adanya poster pemberitahuan terkait dengan BPJS, tujuan dan sasaran yang jelas, dan finansial yang cukup. Faktor penghambatnya SDM yang dimiliki RS tidak sebanding dengan yang berobat (pasien), sering terjadi miskomunikasi antara petugas dengan pasien, alat medis yang belum lengkap, ketidakefisiensian proses klaim BPJS, dan tunggakan pembayaran dari pihak BPJS.
\end{abstract}

Kata Kunci : Pelayanan, Kesehatan, Badan Penyelenggara Jaminan Sosial (BPJS)

\section{ABSTRACT}

The purpose of this study was to analyze BPJS Health services in Kertosono District Hospital Nganjuk District, and to analyze the supporting and inhibiting factors of BPJS Health services in Kertosono District Hospital Nganjuk Regency. The results of this study are: First, health services in Kertosono Regional Hospital Nganjuk said to be very good, it is because of the commitment of the Kertosono Regional Hospital who want to provide health services according to good standards and based on public service standards to the community. Second, the supporting factors in providing services to patients are, the attitude of employees who are friendly and polite, the services provided are satisfactory and the flow is easy, there are poster announcements related to BPJS, clear goals and objectives, and sufficient financial. The inhibiting factors of HR owned by hospitals are not comparable to those treated (patients), frequent miscommunication between officers and patients, incomplete medical devices, inefficiency of the BPJS claim process, and arrears of payment from the BPJS.

Keywords: Services, Health, Badan Penyelenggara Jaminan Sosial (BPJS)

\section{PENDAHULUAN}

Tujuan sebuah negara adalah memberikan kesejahteraan kepada seluruh rakyatnya. Siapapun dan apapun statusnya, berhak mendapatkan kesejahteraan dalam hidupnya, termasuk kesejahteraan dalam hal kesehatan. Jadi keberadaan institusi bernama BPJS (Badan Penyelenggara Jaminan Sosial) adalah salah satu cara untuk dapat memenuhi kebutuhan dasar hidup yang layak dan meningkatkan martabatnya menuju terwujudnya masyarakat Indonesia yang sejahtera, adil dan makmur.

Sebelum BPJS yang dibentuk berdasarkan Undang-Undang Nomor 24 Tahun 2011 berdiri, telah menjalankan beberapa program jaminan sosial, yaitu Jaminan Sosial Tenaga Kerja (JAMSOSTEK) berdasarkan Undang-Undang Nomor 3 Tahun 1992 tentang JAMSOSTEK yang mencakup program jaminan pemeliharaan kesehatan, jaminan kecelakaan kerja, jaminan hari tua, dan jaminan kematian bagi tenaga kerja.

Program tersebut di atas, baru mencakup sebagian kecil masyarakat. Sebagian besar rakyat belum memperoleh perlindungan yang memadai. Di samping itu, pelaksanaan berbagai program jaminan sosial tersebut mampu memberikan perlindungan yang adil dan memadai kepada para peserta sesuai dengan manfaat program yang menjadi hak peserta. Sehubungan dengan hal di atas, dipandang perlu 
menyusun Sistem Jaminan Sosial Nasional yaitu suatu tata cara penyelenggaraan program jaminan sosial oleh beberapa badan penyelenggara jaminan sosial yang dapat menjangkau kepesertaan yang lebih luas serta memberikan manfaat yang lebih besar bagi setiap peserta. Oleh karena itu, untuk mewujudkan tujuan sistem jaminan sosial nasional maka dibentuklah BPJS yaitu BPJS Kesehatan dan BPJS Ketenagakerjaan.

Pembangunan dalam bidang kesehatan merupakan salah satu bagian dari pembangunan nasional, karena kesehatan merupakan salah satu unsur kesejahteraan umum. Pembangunan bidang kesehatan tersebut diarahkan guna mencapai kesadaran, kemauan, dan kemampuan hidup sehat bagi setiap penduduk agar dapat mewujudkan derajat kesehatan yang optimal, sesuai dengan tujuan dan pembangunan kesehatan sebagaimana diamanatkan oleh Pasal 3 Undang-Undang Nomor 36 Tahun 2009 tentang Kesehatan yang menyatakan bahwa "Pembangunan kesehatan bertujuan untuk meningkatkan kesadaran, kemauan, dan kemampuan hidup sehat bagi setiap orang agar terwujud derajat kesehatan masyarakat yang setinggi-tingginya, sebagai investasi bagi pembangunan sumber daya manusia yang produktif secara sosial dan ekonomis".

BPJS Kesehatan hadir sebagai sebuah badan hukum pemerintah yang memiliki tugas khusus yaitu menyelenggarakan jaminan pemeliharaan kesehatan bagi seluruh rakyat Indonesia, terutama untuk Pegawai Negeri Sipil, Penerima Pensiun PNS dan TNI/POLRI, Veteran, Perintis Kemerdekaan beserta keluarganya dan Badan Usaha lainnya ataupun rakyat biasa. Dan bertujuan untuk mewujudkan terselenggaranya pemberian jaminan kesehatan yang layak bagi setiap Peserta dan/atau anggota keluarganya. Badan publik ini terbentuk berdasarkan hasil transformasi dari PT Askes (Persero) yang pelaksanaannya mulai diberlakukan pada tanggal 1 Januari 2014.

Praktik yang terjadi, adanya pengaturan mengenai BPJS belum sepenuhnya berjalan dengan baik, hal tersebut karena sebagian masyarakat masih belum mengerti mengenai sistem rujukan yang ditetapkan dalam BPJS Kesehatan, termasuk adanya keluhan dari masyarakat/pasien tentang biaya kesehatan yang tidak jelas, tidak seperti pada saat berlakunya PT Jamsostek. Permasalahan muncul berkaitan dengan tarif BPJS yang sudah ditetapkan dalam Lampiran Peraturan Menteri Kesehatan Republik Indonesia Nomor 59 Tahun 2014 tentang Standar Tarif Pelayanan Kesehatan Pada Fasilitas Kesehatan Tingkat Lanjutan Dalam Penyelenggara Program Jaminan Kesehatan. Dalam peraturan tersebut, disebutkan bahwa tarif kapitasi untuk rawat jalan RS Pratama, Klinik Pratama, Praktek Dokter, atau Fasilitas Kesehatan yang setara sebesar 8.000 rupiah sampai 10.000 rupiah. Praktik Dokter Gigi di luar Fasilitas Kesehatan A1 atau B1 sebesar 2.000 rupiah, dan masih banyak lagi rincian tarif sesuai yang ada di dalam peraturan tersebut.

Berkaitan dengan layanan BPJS, sejak keberadaanya masih banyak menerima keluhan dan kritikan, menemui kendala dan permasalahan dari program Jaminan Kesehatan Nasioanl. Pada praktiknya rumah sakit selaku penyedia jasa dan pelayanan kesehatan sering dirugikan oleh BPJS Kesehatan dalam hal pembayaran, seperti halnya kasus Kantor Badan Penyelenggara Jaminan Sosial (BPJS) Kesehatan Depok di Ruko Saladin, Margonda, Depok yang didatangi massa dari LSM kesehatan Dewan Kesehatan Rakyat (DKR). Mereka menggeruduk BPJS Kesehatan demi mewakili warga Depok bernama Ignasius. Ignasius datang bersama DKR membawa berbagai surat dokumentasi, terkait perawatan istrinya. Istri Ignasius sudah dirawat lebih dari 29 minggu di Rumah Sakit Dr. Cipto Mangunkusumo (RSCM) Jakarta dan harus membayar Rp150 juta, meski terdaftar sebagai pasien peserta BPJS Kesehatan.

Selain kasus terkait klaim peserta oleh Penyedia Pelayanan Kesehatan yang menyediakan pelayanan kesehatan untuk peserta. Pengajuan klaim oleh Penyedia Pelayanan Kesehatan (PPK) kepada BPJS Kesehatan lumrah ditemui berbagai permasalahan, seperti permasalahan berkas klaim, banyaknya klaim susulan, ketidaksesuian 
tarif yang diajukan rumah sakit dengan tarif INA CBG's atau yang dibayarkan BPJS Kesehatan, kejanggalan pengkodean diagnosis penyakit, ataupun keterlambatan pembayaran klaim oleh BPJS kesehatan. Dengan adanya permasalahan tersebut berakibat tidak adanya kepastian hukum bagi pasien BPJS yang tentunya sudah melakukan kewajibannya dengan membayarkan iuran pada setiap bulan.

Berdasarkan pemaparan di atas, penulis tertarik untuk melakukan penelitian hukum dengan judul "Implementasi Pelayanan Kesehatan Menurut Undang-Undang No. 24 Tahun 2011 Tentang Badan Penyelenggara Jaminan Sosial (BPJS) (Studi di RSUD Kertosono Kabupaten Nganjuk)".

\section{METODE PENELITIAN}

Metode dalam penulisan hukum ini adalah yuridis sosiologis yakni suatu pendekatan dengan berdasarkan norma-norma atau peraturan yang mengikat, sehingga diharapkan dari pendekatan ini dapat diketahui bagaimana hukum yang secara empiris merupakan gejala masyarakat itu dapat dipelajari sebagai suatu variabel penyebab yan menimbulkan akibatakibat pada berbagai segi kehidupan sosial. ${ }^{1}$

Penelitian ini dilakukan di Rumah Sakit Umum Daerah Kertosono Nganjuk. Adapun jenis data yang digunakan dalam penelitian ini adalah data primer dan data sekunder. Data primer merupakan data yang diperoleh langsung dari sumber pertama, yakni diperoleh dari lokasi penelitian, sedangkan data sekunder merupakan data yang diperoleh dari sumber kepustakaan dan dokumentasi.

Sumber data primer adalah para responden yang telah ditunjuk/terpilih dan sumber data sekunder adalah literatur, laporan penelitian, artikel ilmiah, media massa, undangundang/peraturan, brosur, dan bahan-bahan pustaka serta dokumentasi lainnya. ${ }^{2}$

1 Ronny Hanitijo Soemitro, Metodologi Penelitian Hukum dan Jurimetri (Bandung, 1990) hlm. 34-35

\section{HASIL PENELITIAN DAN PEMBAHASAN}

\section{A. Sejarah RSUD Kertosono}

Rumah Sakit Umum Daerah Kertosono adalah Rumah Sakit Klas C yang berlokasi di Kecamatan Kertosono Kabupaten Nganjuk, yang secara administrasi merupakan rumah sakit milik dari pemerintah kabupaten nganjuk. Bangunan RSUD Kertosono awalnya merupakan sarana pelayanan kesehatan yang bertujuan untuk memberikan pelayanan kesehatan pada karyawannya pada jaman penjajahan sekitar tahun 1920, Hendels Vereeniging Amsterdam (HVA) suatu perusahaan milik pemerintah Hindia Belanda yang didirikan bersamaan di bangunnya pabrik Gula Lestari yang berlokasi di Kecamatan Patianrowo. Namun setelah Proklamasi Kemerdekaan Republik Indonesia , Sarana pelayanan kesehatan tersebut diambil alih oleh pemerintah Republik Indonesia dan sekarang dibawah kepemilikan pemerintah Kabupaten Nganjuk sarana pelayanan kesehatan tersebut dirubah atau dikembangkan menjadi rumah sakit yang diberi nama Rumah Sakit Umum Daerah Kertosono yang lokasinya di Kabupaten Nganjuk bagian timur yaitu di wilayah Kecamatan Kertosono.

Seiring dengan adanya perkembangan dan tuntutan jaman dan semakin banyaknya kepercayaan yang diberikan oleh masyarakat membuat bangunan di RSUD Kertosono terasa kurang memadai dan harus dilakukan pengembangan. Tetapi kalau melihat kondisi geografis di sekitar RSUD Kertosono dirasa tidak memungkinkan untuk pengembangan lagi. Kemudian bila dilihat dari segi fisik bangunan RSUD Kertosono tidak bisa menambah tempat layanan baru karena keterbatasan lahan. Dari segi pencegahan dan pengendalian infeksi tidak memungkinkan untuk menambah ruang isolasi, Loundry, CSSD, OK dan Intalasi GIZI apalagi menambah gedung untuk menunjang kegiatan di Radiologi yakni CT Scan karena tidak

2 Hilman Hadikusuma, Metode Pembuatan Kertas Kerja atau Skripsi Ilmu Hukum (Bandung, 1995), hlm. 45-46 
memenuhi persyaratan. Sedangkan untuk mencapai hal tersebut memerlukan biaya yang tidak sedikit.

Untuk itu dalam rangka memberikan akses pelayanan kesehatan yang memadai bagi masyarakat Nganjuk Pemerintah Nganjuk mendirikan gedung Rumah Sakit baru yang bertujuan untuk mengakomodir kebutuhan atau pelayanan kesehatan yang semakin bertambah setiap tahunnya. Rumah Sakit Daerah Kertosono yang sebelumnya terletak di kelurahan Banaran, tepatnya di jalan Supriadi Nomor 29 Kertosono di pindahkan ke Gedung Rumah Sakit baru yang terletak di desa Kepuh tepatnya jalan Panglima Sudirman Nomor 16 Kertosono.

\section{B. Aturan Normatif Terkait dengan Jaminan Kesehatan}

Hak atas pelayanan kesehatan yang baik merupakan hak bagi setiap manusia, setiap warga negara berhak untuk mendapatkan layanan kesehatan dan hidup sehat, hal tersebut secara normatif telah diatur dalam UndangUndang Dasar Negara Indonesia. Disamping itu, hak terhadap pelayanan kesehatan juga diatur dalam berbagai peraturan perundang-undangan, yakni:

\section{Undang-Undang Dasar Negara Republik Indonesia Tahun 1945}

Kesehatan merupakan kondisi sejahtera dari badan, jiwa, dan sosial yang memungkin setiap orang produktif secara ekonomis (Ps. 1 point (1) UU Nomor 23 Tahun 1992 tentang Kesehatan). Karena itu kesehatan merupakan dasar dari diakuinya derajat kemanusiaan. Tanpa kesehatan, seseorang menjadi tidak sederajat secara kondisional. Tanpa kesehatan, seseorang tidak akan mampu memperoleh hak-haknya yang lain. Seseorang yang tidak sehat dengan sendirinya akan berkurang haknya atas hidup, tidak bisa memperoleh dan menjalani pekerjaan yang layak, tidak bisa menikmati haknya untuk berserikat dan berkumpul serta mengeluarkan pendapat, dan tidak bisa memperoleh pendidikan demi masa depannya. Singkatnya, seseorang tidak bisa menikmati sepenuhnya kehidupan sebagai manusia.
Pentingnya kesehatan sebagai hak asasi manusia dan sebagai kondisi yang diperlukan untuk terpenuhinya hak-hak lain telah diakui secara internasioal. Hak atas kesehatan meliputi hak untuk mendapatkan kehidupan dan pekerjaan yang sehat, hak untuk mendapatkan pelayanan kesehatan, dan perhatian khusus terhadap kesehatan ibu dan anak. Pasal 25 Universal Declaration of Human Rights (UDHR) menyatakan:

a. Setiap orang berhak atas taraf kehidupan yang memadai untuk kesehatan dan kesejahteraan dirinya sendiri dan keluarganya, termasuk hak atas pangan, sandang, papan, dan pelayanan kesehatan, pelayanan sosial yang diperlukan, serta hak atas keamanan pada saat menganggur, sakit, cacat, ditinggalkan oleh pasangannya, lanjut usia, atau keadaan-keadaan lain yang mengakibatkan merosotnya taraf kehidupan yang terjadi diluar kekuasaannya.

b. Ibu dan anak berhak mendapatkan perhatian dan bantuan khusus. Semua anak, baik yang dilahirkan di dalam maupun di luar perkawinan, harus menikmati perlindungan sosial yang sama.

Instrumen internasional lain tentang hak atas kesehatan juga terdapat pada Pasal 12 dan 14 Konvensi Internasional tentang Penghapusan Semua Bentuk Diskriminasi terhadap Perempuan, dan ayat 1 Deklarasi Universal tentang Pemberantasan Kelaparan dan kekurangan Gizi.

Pada lingkup nasional, Pasal $28 \mathrm{H}$ ayat (1) UUD 1945 menyatakan bahwa setiap orang berhak hidup sejahtera lahir dan batin, bertempat tinggal, dan mendapatkan lingkungan hidup yang baik dan sehat serta berhak memperoleh pelayanan kesehatan. Pasal 9 UU Nomor 39 Tahun 1999 tentang Hak Asasi Manusia menyatakan bahwa:

a. Setiap orang berhak untuk hidup, mempertahankan hidup dan meningkatkan taraf kehidupannya.

b. Setiap orang berhak hidup tenteram, aman, damai, bahagia, sejahtera, lahir dan batin.

c. Setiap orang berhak atas lingkungan hidup yang baik dan sehat. 


\section{Undang-Undang BPJS Kesehatan}

Dalam pembukaan Undang-Undang

Dasar Negara Republik Indonesia Tahun 1945 diamanatkan bahwa tujuan negara adalah untuk meningkatkan kesejahteraan rakyat. Dalam Perubahan Keempat UndangUndang Dasar Negara Republik Indonesia Tahun 1945, tujuan tersebut semakin dipertegas yaitu dengan mengembangkan sistem jaminan sosial bagi kesejahteraan seluruh rakyat. Sehingga pemerintah menerbitkan Undang-Undang BPJS.

Didalam ketentuan umum Undang-Undang Nomor 24 Tahun 2011 Pasal 1 Ayat (1) menyebutkan bahwa Badan Penyelenggara Jaminan Sosial yang selanjutnya disingkat BPJS adalah badan hukum yang dibentuk untuk menyelenggarakan program jaminan sosial. Jaminan Sosial adalah salah satu bentuk perlindungan sosial untuk menjamin seluruh rakyat agar dapat memenuhi kebutuhan dasar hidupnya yang layak.

BPJS bertujuan untuk mewujudkan terselenggaranya pemberian jaminan terpenuhinya kebutuhan dasar hidup yang layak bagi setiap Peserta dan/atau anggota keluarganya. Karena pada dasarnya setiap manusia berhak untuk mendapatkan kesehatan, dan setiap warga negara berhak untuk hidup sehat sebagaimana telah diatur dalam konstitusi kita yakni UUD NRI 1945. Sehingga berdasarkan hal tersebut keluarlah peraturan berupa Undang-Undang BPJS.

\section{Undang-Undang Pelayanan Publik}

Undang-Undang Pelayanan Publik adalah undang-undang yang mengatur tentang prinsipprinsip pemerintahan yang baik yang merupakan efektifitas fungsi-fungsi pemerintahan itu sendiri pelayanan publik yang dilakukan oleh pemerintahan atau korporasi yang efektif dapat memperkuat demokrasi dan hak asasi manusia, mempromosikan kemakmuran ekonomi, kohesi sosial, mengurangi kemiskinan, meningkatkan perlindungan lingkungan, bijak dalam pemanfaatan sumber daya alam, memperdalam kepercayaan pada pemerintahan dan administrasi publik.
Negara berkewajiban melayani setiap warga negara dan penduduk untuk memenuhi hak dan kebutuhan dasarnya dalam kerangka pelayanan publik yang merupakan amanat Undang-Undang Dasar Negara Republik Indonesia Tahun 1945 yang salah satunya ialah hak pelayanan kesehatan, membangun kepercayaan masyarakat atas pelayanan publik yang dilakukan penyelenggara pelayanan publik merupakan kegiatan yang harus dilakukan seiring dengan harapan dan tuntutan seluruh warga negara dan penduduk tentang peningkatan pelayanan publik, sebagai upaya untuk mempertegas hak dan kewajiban setiap warga negara dan penduduk serta terwujudnya tanggung jawab negara dan korporasi dalam penyelenggaraan pelayanan publik, diperlukan norma hukum yang memberi pengaturan secara jelas, sebagai upaya untuk meningkatkan kualitas dan menjamin penyediaan pelayanan publik sesuai dengan asas-asas umum pemerintahan dan korporasi yang baik serta untuk memberi perlindungan bagi setiap warga negara dan penduduk dari penyalahgunaan wewenang di dalam penyelenggaraan pelayanan publik.

Dalam Undang-Undang Pelayanan Publik terdapat pengertian Pelayanan publik merupakan kegiatan atau rangkaian kegiatan dalam rangka pemenuhan kebutuhan pelayanan sesuai dengan peraturan perundang-undangan bagi setiap warga negara dan penduduk atas barang, jasa, dan/atau pelayanan administratif yang disediakan oleh penyelenggara pelayanan publik, Penyelenggara pelayanan publik atau Penyelenggara merupakan setiap institusi penyelenggara negara, korporasi, lembaga independen yang dibentuk berdasarkan undangundang untuk kegiatan pelayanan publik, dan badan hukum lain yang dibentuk semata-mata untuk kegiatan pelayanan publik, Atasan satuan kerja Penyelenggara merupakan pimpinan satuan kerja yang membawahi secara langsung satu atau lebih satuan kerja yang melaksanakan pelayanan publik, Organisasi penyelenggara pelayanan publik atau Organisasi Penyelenggara merupakan satuan kerja penyelenggara pelayanan publik yang berada di lingkungan 
institusi penyelenggara negara, korporasi, lembaga independen yang dibentuk berdasarkan undang-undang untuk kegiatan pelayanan publik, dan badan hukum lain yang dibentuk semata-mata untuk kegiatan pelayanan publik, Pelaksana pelayanan publik atau Pelaksana merupakan pejabat, pegawai, petugas, dan setiap orang yang bekerja di dalam Organisasi Penyelenggara yang bertugas melaksanakan tindakan atau serangkaian tindakan pelayanan publik, Masyarakat merupakan seluruh pihak, baik warga negara maupun penduduk sebagai orang-perseorangan, kelompok, maupun badan hukum yang berkedudukan sebagai penerima manfaat pelayanan publik, baik secara langsung maupun tidak langsung, Standar pelayanan merupakan tolak ukur yang dipergunakan sebagai pedoman penyelenggaraan pelayanan dan acuan penilaian kualitas pelayanan sebagai kewajiban dan janji Penyelenggara kepada masyarakat dalam rangka pelayanan yang berkualitas, cepat, mudah, terjangkau, dan terukur, Maklumat pelayanan merupakan pernyataan tertulis yang berisi keseluruhan rincian kewajiban dan janji yang terdapat dalam standar pelayanan, Sistem informasi pelayanan publik atau Sistem Informasi merupakan rangkaian kegiatan yang meliputi penyimpanan dan pengelolaan informasi serta mekanisme penyampaian informasi dari Penyelenggara kepada masyarakat dan sebaliknya dalam bentuk lisan, tulisan Latin, tulisan dalam huruf Braile, bahasa gambar, dan/atau bahasa lokal, serta disajikan secara manual ataupun elektronik, Mediasi merupakan penyelesaian sengketa pelayanan publik antarpara pihak melalui bantuan, baik oleh ombudsman sendiri maupun melalui mediator yang dibentuk oleh ombudsman, Ajudikasi merupakan proses penyelesaian sengketa pelayanan publik antarpara pihak yang diputus oleh ombudsman, Menteri merupakan menteri dimana kementerian berada yang bertanggung jawab pada bidang pendayagunaan aparatur negara, Ombudsman merupakan sebuah lembaga negara yang mempunyai kewenangan mengawasi penyelenggaraan pelayanan publik, baik yang diselenggarakan oleh penyelenggara negara dan pemerintahan termasuk yang diselenggarakan oleh badan usaha milik negara, badan usaha milik daerah, dan badan hukum milik negara serta badan swasta, maupun perseorangan yang diberi tugas menyelenggarakan pelayanan publik tertentu yang sebagian atau seluruh dananya bersumber dari anggaran pendapatan dan belanja negara dan/atau anggaran pendapatan dan belanja daerah.

Dalam hal ini, BPJS Kesehatan dan rumah sakit sebagai sebuah institusi dibidang kesehatana harus memberikan suatu pelayanan publik yang berpedoman kepada asas-asas dalam penyelenggaraan pelayanan publik. Hal tersebut agar fungsi dan tujuan dari BPJS Kesehatan dan Rumah Sakit tercapai untuk menciptakan masyarakat yang sehat dan sebagai pemenuhan dari UUD NRI 1945.

\section{Pelayanan Kesehatan di RSUD Kertosono Kabupaten Nganjuk}

Pelaksanaan pelayanan yang diberikan oleh RSUD Kertosono Nganjuk dapat dilihat berdasarkan Undang-Undang Pelayanan Publik, standar pelayanan yang diberikan, saranan dan prasarana, pemberi layanan baik Dokter maupun Perawat, dan yang terakhir ialah masyarakat penerima layanan. Dari hal tersebut dapat dilihat bagaimana pelaksanaan pelayanan yang diberikan oleh pihak rumah sakit.

\section{Pelaksanaan Berdasarkan Undang- Undang Pelayanna Publik}

Dalam Undang-Undang Dasar Negara Republik Indonesia Tahun 1945 mengamanatkan "bahwa negara berkewajiban melayani setiap warga negara dan penduduk untuk memenuhi hak dan kebutuhan dasarnya dalam kerangka pelayanan publik".

Pelayanan publik adalah kegiatan atau rangkaian kegiatan dalam rangka pemenuhan kebutuhan pelayanan sesuai dengan peraturan perundang-undangan bagi setiap warga negara dan penduduk atas barang, jasa, dan/atau pelayanan administratif yang disediakan oleh penyelenggara pelayanan publik. Jadi pelayanan publik yang diberikan oleh RSUD 
Kertosono merupakan hak dari masyarakat sebagaimana diamanatkan UUD NRI 1945.

Adapun ruang lingkup pelayanan publik sebagaimana dalam Undang-Undang Nomor 25 Tahun 2009 tentang Pelayanan Publik Pasal 5 Ayat (1) menyatakan "Ruang lingkup pelayanan publik meliputi pelayanan barang publik dan jasa publik serta pelayanan administratif yang diatur dalarn peraturan perundang-undangan".

Ruang lingkup sebagaimana dimaksud diatas meliputi pendidikan, pengajaran, pekerjaan dan usaha, tempat tinggal, komunikasi dan informasi, lingkungan hidup, kesehatan, jaminan sosial, energi, perbankan, perhubungan, sumber daya alarn, pariwisata, dan sektor strategis lainnya. Artinya, pelayanan kesehatan merupakan bagian dari pelayanan publik yang wajib diberikan oleh rumah sakit dalam hal adalah RSUD Kertosono Nganjuk.

Pelaksanaan pelayanan kesehatan di RSUD Kertosono Nganjuk sudah sesuai dengan prosedur dan asas-asas pelayanan publik. Yakni melayani dengan transparan, akuntabilitas, partisipatif, dan kesamaan hak tanpa adanya diskriminasi sesama pasien baik pengguna BPJS maupun tidak.

\section{Pemberi}

Layanan

(Dokter/Perawat/Petugas Rumah Sakit)

Keandalan pegawai memberikan pelayanan yang cepat sangat diharapkan masyarakat, seperti halnya loket pendaftaran RSUD Kertosono Nganjuk memberikan pelayanan yang cepat, petugas berdasarkan prosedur yang telah ditentukan, meskipun pada dasarnya jumlah loket pendaftaran masih kurang. Berdasarkan hasil wawancara kepada pasien BPJS Kesehatan bahwa pegawai sudah memberikan pelayanan yang cepat dengan pasien melengkapi persyaratan dan mengikuti alur pelayanan yang ada maka proses pelayanan akan cepat dan pelayanan disesuaikan dengan nomor antrian, persyaratan yang diberikan mudah dan tidak berbelit-belit. Berdasarkan hasil observasi pelayanan loket pendaftaran cepat, persyaratan sangat mudah dan tidak berbelit-belit, antara pasien BPJS Kesehatan dan Non BPJS tidak jauh berbeda, pasien BPJS Kesehatan membawa kartu pengguna BPJS, mengambil nomor antrian dipanggil untuk mendaftar di loket umum mengisi rekam medik kemudian mengecek data di loket BPJS dan menunggu panggilan pelayanan kesehatan sesuai dengan urutan rekam medik yang sudah ditentukan begitu juga pasien umum membawa kartu berobat, mengambil nomor antrian, mengisi rekam medik dan menunggu panggilan pelayanan kesehatan, pasien datang langsung dilayani dan disesuaikan nomor antrian dan prosedur pelayanan sudah terpampang didinding loket pelayanan.

Selain keandalan petugas rumah sakit dalam memberikan pelayanan kepada pasien, Dokter dan Perawat nya pun tidak kalah handalnya, dalam melayani pasien dan keluarga pasien Dokter dan Perawat di RSUD Kertosono Nganjuk sangatlah ramah dan sopan. Dokter dapat menjelaskan dan memberikan penjelasan kepada pasien maupun keluarga dari pasien tersebut dengan baik dan dapat dimengerti oleh pasien maupun keluarga pasien. Hal tersebut juga diungkapkan oleh seorang keluarga dari pasien yang sedang dirawat inap di RSUD Kertosono Nganjuk. (M nama inisial) menyatakan bahwa Petugas, Dokter dan Perawatnya baik-baik, ramah dan sopan dalam menangani pasien serta selalu memberikan solusi terbaik untuk kesehatan pasien.

Selain keandalan dari Petugas rumah sakit, Dokter dan Perawat dalam memberikan pelayanan kepada pasien, respon atau kesigapan petugas loket pendaftaran, Dokter dan Perawat di RSUD Kertosono Nganjuk untuk mengenali, memahami kebutuhan pasien BPJS Kesehatan sangat membantu pasien pengguna BPJS dengan disediakan tempat menampung aspirasi seperti kotak saran. Seperti yang diungkapkan oleh pasien BPJS "Kalau saya berobat pegawainya membantu, semuanya ramah-ramah, dokternya juga baik-baik, kalau kita tidak mengerti langsung dijelaskan, disini juga disediakan kotak saran, jadi ketika kita punya masalah dan keluhan bisa langsung disampaikan" (Keluarga Pasien BPJS Kesehatan Ibu Sarinah). Sesuai dengan hasil observasi ke RSUD Kertosono Nganjuk bahwa sudah disediakan kotak saran di loket pendaftaran, dipoli kesehatan, dimading 
yang telah disediakan. Adanya perhatian petugas dengan menyediakan kotak saran untuk pasien BPJS Kesehatan yang sangat membantu untuk memperbaiki kualitas pelayanan agar dapat memberikan pelayanan yang baik sesuai dengan yang di harapkan masyarakat dan sesuai dengan prosedur undang-undang BPJS.

Jaminan pelayanan yang berkualitas selalu diberikan bagi pasien BPJS Kesehatan untuk mendapatkan pelayanan yang nyaman seperti sikap pegawai yang ramah, sopan santun serta rasa aman bebas dari bahaya selama dilingkungan rumah sakit telah diberikan dengan baik dan diterima masyarakat. Adapun jaminan yang diberikan kepada pasien sudah baik, pegawai memberikan pelayanan dengan ramah, sopan santun dalam melayani masyarakat dengan ikhlas santun dan senyum sudah diterapkan, tanggapan dari pasien BPJS Kesehatan masyarakat yang merasa puas selain sikap pegawai dan tidak kalah penting kondisi keamanan kendaraan juga di jaga oleh petugas parkir rumah sakit. Dalam memberikan pelayanan kepada pasien sikap petugas yang sopan, ramah dan kondisi kemanan terjaga akan mempermudah pelayanan dan memberikan kenyamanan bagi pasien pengguna BPJS Kesehatan maupun pasien non BPJS.

\section{Masyarakat Penerima Layanan}

Masyarakat yang memanfaatkan kartu BPJS Kesehatan, terus meningkat. Menurut Staf Ahli Bidang Komunikasi Publik dan Partisipasi Masyarakat BPJS Kesehatan, Irfan Humaidi, pada 2014 masyarakat yang memanfaatkan kartu BPJS Kesehatan sebanyak 92,3 juta. Pada 2015 meningkat menjadi 146,7 juta. Bahkan, pada 2016 jumlahnya meningkat menjadi 177,8 juta kunjungan ke fasilitas kesehatan.

Total pemanfaatan di 2016 ini terdiri dari kunjungan ke fasilitas kesehatan tingkat pertama, seperti puskesmas, klinik pratama, dan dokter praktek perorangan. Rinciannya, mereka yang rawat jalan di poliklinik dan rumah sakit sebanyak 49,3 juta, dan rawat inap 7,6 juta. Bila ditambah angka rujukan sebesar 15,1 juta, maka total pemanfaatan JKN-KIS adalah 192,9 juta.

Masyarakat penerima layanan dalam hal ini adalah warga masyarakat Nganjuk secara keseluruhan merupakan masyarakat yang menerima secara langsung layanan yang diberikan oleh pihak rumah sakit (RSUD Kertosono). Dimana dari hasil observasi dan pengamatan yang dilakukan serta dilakukan wawancara dengan masyarakat penerima layanan langsung didapat beberapa kesimpulan, yaitu:

a. Pelayanan BPJS Kesehatan di RSUD Kertosono sangat memuaskan, meskipun sering terjadi antrian panjang pada loket pendaftaran yang diakibatkan oleh banyaknya masyarakat yang berobat di RSUD Kertosono Nganjuk;

b. Pelayanan yang diberikan merupakan pelayanan terbaik berdasarkan SOP rumah sakit dan perintah Undang-Undang; dan

c. Tidak ada perbedaan pelayanan yang diberikan pihak rumah sakit kepada pasien pengguna BPJS maupun non BPJS.

Hasil kepuasan terhadap pelayanan kesehatan yang diberikan oleh RSUD Kertosono Nganjuk tersebut berdasarkan hasil penelitian, observasi, dan wawancara langsung stackholder terkait. Tentukan dalam menyimpulkan hasil tersebut tidak lepas dari adanya perbandingan pelayanan kesehatan bagi pasien pengguna BPJS Kesehatan pada Puskesmas, Klinik, atau rumah sakit lainnya.

Perbandingan yang penulis lakukan disini ialah dengan melakukan perbandingan pelayanan BPJS Kesehatan pada Puskesmas Dinoyo Kota Malang. Dimana pelayanan BPJS Kesehatan di Puskesmas Dinoyo tersebut berdasarkan penelitian, observasi, dan wawancara kepada pihak terkait juga menunjukkan hasil yang sama dengan penelitian di RSUD Kertosono Nganjuk. Dimana, dalam setiap prosesnya sama, tidak ada perbedaan. Namun yang menarik dalam proses pelayanan kesehatan bagi pasien pengguna BPJS Kesehatan ialah ada sebuah proses alur atau tata cara terkait penggunaan BPJS Kesehatan, ialah masyarakat atau pasien pengguna BPJS Kesehatan dibuat kerepotan dengan harus bolak balik kepada instansi-instansi yang berkaitan dengan BPJS. Seperti temuan di Puskesmas Dinoyo, pasien pengguna BPJS Kesehatan 
mengaku harus bolak balik membuat laporan pelayanan, mulai dari laporan kepada rumah sakit apabila mendapat rujukan dari puskesmas, kemudian dari rumah sakit juga harus malaporkan kepada pihak BPJS (Kantor Vedika Center BPJS) bahwa pihak rumah sakit yang ditunjuk sudah mendapat pelayanan dari rumah sakit.

\section{Faktor Pendukung dan Penghambat dalam Pelayanan Kesehatan BPJS Kesehatan di RSUD Kertosono Kabupaten Nganjuk}

Memberikan pelayanan yang baik dan berkualitas bagi pasien BPJS Kesehatan tidak lepas dari faktor pendukung dan juga penghambat. Baik itu faktor dari lingkungan rumah sakit maupun dari dalam diri pegawai bahkan dari masyarakat sekitar. Faktor pendukung dan faktor penghambat merupakan faktor yang memberikan dampak positif dan dampak negatif terhadap pelaksanaan program BPJS Kesehatan di RSUD Kertosono Kabupaten Nganjuk.

\section{Faktor pendukung}

Adapun faktor-faktor pendukung pelaksanaan BPJS Kesehatan di RSUD Kertosono Nganjuk adalah sebagai berikut:

a. Sikap pegawai dalam memberikan pelayanan kepada pasien dengan ramah berbicara sopan santun sesuai dengan slogan yang sudah dipegang teguh sehingga masyarakat merasa nyaman dengan pelayanan yang diberikan;

b. Pelayanan yang diberikan sangat mudah dengan persyaratan serta alur pelayanan yang sederhana telah memberikan pelayanan yang baik dan juga alur pelayanan, persyaratan, serta jadwal dan waktu pelayanan sudah dibuat dalam bentuk tabel dan ditempel didinding sehingga pasien mudah untuk memahaminya;

c. Adanya inisiatif pihak RSUD Kertosono Kabupaten Nganjuk untuk membuat lift live. Lift live yaitu berupa poster yang berguna bagi masyarakat sekitar RSUD Kertosono Kabupaten Nganjuk untuk memperoleh informasi terkait BPJS Kesehatan;

d. Adanya kejelasan tujuan sasaran dalam pelaksanaan program BPJS Kesehatan di RSUD Kertosono Kabupaten Nganjuk dengan meningkatkan pelayanan yang lebih baik lagi dari sebelumnya;

e. Ketersediaan fasilitas yang memadai yang ditunjukkan dengan fasilitas dengan kualitas dan kuantitas yang memadai seperti alat-alat kesehatan atau medis yang digunakan untuk menangani pasien di RSUD Kertosono Kabupaten Nganjuk, fasilitas di ruang tunggu dan adanya aula untuk tempat pelaksanaan sosialisasi;

f. Finansial yang cukup untuk Kebutuhan operasional rumah sakit yang ditunjang dari berbagai sumber dana yaitu: APBD (Anggaran Pendapatan Belanja Daerah), BOK (Bantuan Operasional Kesehatan), dan JKN (Jaminan Kesehatan Nasional).

\section{Faktor penghambat}

Ada beberapa faktor yang menjadi hambatan dalam proses layanan kesehatan bagi peserta BPJS Kesehatan di RSUD Kertosono Nganjuk, diantaranya adalah:

a. Ketidaksesuaian antara jumlah pasien yang kadang ramai, sementara jumlah pegawai masih perlu penambahan, pegawai tidak hanya mendaftar nama pasien tetapi juga mengantar lis pasien ke pelayanan kesehatan, sehingga masih perlu penambahan pegawai (SDM) pada bagian pendafataran.

b. Sering terjadinya miskomunikasi, cara penyampaian yang kurang jelas kepada masyarakat tentang BPJS Kesehatan sehingga menyebabkan terjadinya kesalahpahaman antara pelaksana dan penerima layanan. Meskipun pelayanan yang diberikan oleh petugas rumah sakit sudah baik, sopan dan ramah kepada pasien masih saja terjadi miskomunikasi atau kesalahpahaman antara petugas dengan pasien/keluarga pasien. Ini biasanya terjadi karena faktor kurangnya pendidikan yang dimiliki pasien BPJS. 
c. Jumlah SDM yang kurang memadai, kurangnya jumlah pegawai yang bekerja di RSUD Kertosono Nganjuk menyebabkan terjadinya penumpukkan pekerjaan yang seharusnya sudah dilakukan oleh masingmasing bidangnya. Seperti yang ditemui oleh penulis pada saat melakukan observasi ke RSUD Kertosono Nganjuk, banyak terdapat antrian di loket pendaftaran dan di apotik rumah sakit.

d. Alat-alat medis yang belum lengkap, RSUD Kertosono Nganjuk belum memiliki alat-alat medis yang lengkap, hal tersebut berdasarkan hasil observasi dan wawancara dengan pasien yang pernah berobat di RSUD Kertosono Nganjuk. Berdasarkan keterangan tersebut, hal-hal yang pernah terjadi dan dialami oleh pasien tersebut yang menyatakan pernah dirujuk ke rumah sakit lain karena alasan keterbatasan alat medis. (wawancara dengan ibu R keluarga dari pasien RSUD Kertosono Nganjuk).

e. Faktor penghambat pelayanan kesehatan bagi pasien pengguna BPJS Kesehatan di RSUD Kertosono yang terakhir ialah kendala keterlambatan pencairan dana atau adanya tunggakan dari pihak BPJS itu sendiri, tunggakan pencairan dana dari pihak BPJS ke RSUD Kertosono pernah selama 6 bulan, bahkan sampai dengan penelitian ini berlangsung tunggakan BPJS kepada RSUD Kertosono sudah mencapai 7 bulan. Hal inilah yang menjadikan faktor penyebab terhambatnya pelaksanaan kesehatan di RSUD Kertosono, akan tetapi pihak rumah sakit tidak semerta-merta menolak pasien pengguna BPJS Kesehatan yang ingin berobat, melainkan tetap dilayani sambil menunggu proses dari BPJS berjalan.

Disamping faktor diatas, ada juga kendala yang dihadapi oleh pasien pengguna BPJS Kesehatan, yakni kendala pada efektivitas prosedur penggunaan BPJS Kesehatan. Dimana proses klaim yang begitu panjang terkadang mengakibatkan pasien terlambat untuk ditangani. Hal tersebut berdasarkan teori efektivitas belum memenihi kriteria efektif untuk dikatakan sebagai aturan hukum.

\section{E. Upaya untuk Mengatasi Faktor Penghambat Layanan Kesehatan}

Berdasarkan faktor-faktor penghambat pelayanan kesehayan bagi pengguna BPJS Kesehatan, maka upaya yang harus dilakukan untuk mengatasi faktor tersebut ialah sebagai berikut:

\section{Menambah SDM di Rumah Sakit}

Untuk menghasilkan pelayanan yang berkualitas, rumah sakit harus menambah dan memanajemen sumber daya manusia yang dimiliki oleh rumah sakit. Manajemen sumber daya manusia dapat diartikan pula sebagai suatu pengelolaan dan pendayagunaan sumber daya yang ada pada individu (pegawai). Pengelolaan dan pendayagunaan tersebut dikembangkan secara maksimal di dalam dunia kerja untuk mencapai tujuan organisasi dan pengembangan individu pegawai rumah sakit.

Menurut A. A. Anwar Prabu Mangkunegara, "Manajemen sumber daya manusia merupakan suatu perencanaan, pengorganisasian, pengkoordinasian, pelaksanaan, dan pengawasan terhadap pengadaan, pengembangan, pemberian balas jasa, pengintegrasian, dan pemisahan tenaga kerja dalam rangka mencapai tujuan organisasi”.

RSUD Kertosono Nganjuk memerlukan Pekerja (pegawai) untuk menunjang kinerja rumah sakit, selama ini SDM RSUD Kertosono Nganjuk dapat dikatakan kurang dibanding dengan jumlah pasien yang dirawat. Hal tersebut mengakibatkan terjadinya antrian panjang pada loket pendafataran dan loket penukaran obat yang tersedia di rumah sakit. Oleh sebab itu pihak rumah sakit dalam hal ini adalah RSUD Kertosono Nganjuk perlu untuk menambah SDM nya.

\section{Melengkapi Sarana dan Prasarana Rumah Sakit}

Secara umum prasarana dan sarana adalah alat penunjang keberhasilan suatu proses upaya yang dilakukan di dalam pelayanan publik, karena apabila kedua hal ini tidak tersedia maka semua kegiatan yang dilakukan tidak akan dapat 
mencapai hasil yang diharapkan sesuai dengan rencana.

Prasarana dan sarana adalah merupakan seperangkat alat yang digunakan dalam suatu proses kegiatan baik alat tersebut adalah merupakan peralatan pembantu maupun peralatan utama, yang keduanya berfungsi untuk mewujudkan tujuan yang hendak dicapai.

Prasarana yang harus tersedia dalam rumah sakit yaitu meliputi:
a. instalasi air;
b. instalasi mekanikal dan elektrikal;
c. instalasi gas medik;
d. instalasi uap;
e. instalasi pengelolaan limbah;
f. pencegahan dan penanggulangan kebakaran;
g. petunjuk, standar dan sarana evakuasi saat terjadi keadaan darurat;
h. instalasi tata udara; sistem informasi dan komunikasi; dan
i. ambulan.

Semua prasarana tersebut harus memenuhi standar pelayanan, keamanan, serta keselamatan dan kesehatan kerja penyelenggaraan rumah sakit, untuk itu maka prasarana tersebut harus dalam keadaan terpelihara dan berfungsi dengan baik.

Sarana dan Prasarana diatas sebenarnya sudah ada di RSUD Kertosono Nganjuk, namun Prasarana penunjang lainnya seperti kurangnya alat-alat medis sehingga ada pengakuan dari pasien untuk dirujuk ke rumah sakit lain karena alasan alat medis tidak lengkap/kurang, akses wifi yang lelet sehingga susah mengakses informasi, kurangnya loket pendaftaran sehingga sering terjadi antrian panjang dibagian pendafataran. Oleh sebab itu, sarana dan prasarana yang seperti inilah yang perlu ditingkatkan oleh pihak rumah sakit.

\section{Penyederhanaan \\ Pengajuan BPJS}

Sebenarnya syarat-syarat untuk mengajukan klaim BPJS atau berobat dengan menggunakan BPJS sangatlah mudah, yakni dengan fotocopy KTP, fotocopy KK (bagi pemula), dan fotocopy kartu BPJS. Namun pada faktanya, meskipun syarat-syarat tersebut sangat sederhana, masih banyak pasien pengguna BPJS Kesehatan yang tidak lengkap persyaratan administrasinya. Seperti, kurangnya fotocopy KTP, bahkan ada pula yang tidak membawa kartu BPJS ke rumah sakit dengan alasan yang sedemikian rupa.

Hal tersebut menjadi dilema bagi pihak rumah sakit, dilain sisi pasien harus segera ditangani, dilain sisi apabila persyaratan belum lengkap klaim BPJS Kesehatan tidak dapat dilakukan. Untuk mencegah hal tersebut terulang kembali, maka penulis menyarankan untuk mempermudah lagi syarat-syarat untuk mengajukan klaim BPJS Kesehatan, karena hal tersebut berurusan dengan kondisi dan kesehatan pasien, bahkan nyawa pasie taruhannya apabila pasien tersebut tidak mendapat tindakan medis yang segera hanya karena menunggu persyaratan lengkap.

Disamping syarat-syarat kelengkapan yang menjadi kendala, ada faktor-faktor lain yang menjadi faktor penghambat layanan BPJS Kesehatan. Yaitu, mekanisme untuk pengajuan klaim BPJS Kesehatan harus mendaftar terlebih dahulu di Puskesmas/Klinik yang bekerjasama dengan BPJS Kesehatan, setelah itu baru dilakukan pemeriksaan/diagnosa, setelah mengetahui hasilnya baru Puskesmas/Klinik memberikan rujukan ke rumah sakit yang ditunjuk. Hal tersebut menurut hemat penulis merupakan suatu yang tidak efisien karena orang sakit tidak tahu kapan datangnya. Semisal hari ini tiba-tiba ada masyarakat pengguna BPJS Kesehatan sakit mendadak dan membutuhkan penanganan medis segera, hal tersebut penulis rasa kurang efektif untuk diterapkan.

Efektifnya, tata cara atau prosedur klaim BPJS Kesehatan seharusnya dipermudah. Yaitu, tidak perlu mendaftar ke Puskesmas/Klinik terlebih dahulu, kalau memang sudah terdaftar sebagai anggota peserta BPJS Kesehatan dan orang tersebut mengalami sakit dan butuh untuk berobat ataupun penanganan medis maka cukup dengan langsung datang ke rumah sakit/puskesmas/klinik yang sudah bekerja sama dengan BPJS Kesehatan dengan cukup membawa kartu anggota BPJS Kesehatan. Hal tersebut penulis rasa lebih efisien dan lebih 
membantu bagi masyarakat khususnya pengguna BPJS Kesehatan.

\section{Ketepatan Waktu Pembayaran dari Pihak BPJS kepada Rumah Sakit}

Untuk dapat memberikan pelayanan kesehatan yang baik, efektif dan tepat sasaran maka pihak BPJS tidak boleh terjadi keterlambatan pembayaran kepada pihak rumah sakit, karena dalam proses pelayanan kesehatan butuh anggaran seperti pengadaan alat-alat medis, obat-obatan dan lainnya. Jika hal tersebut terjadi maka akan mempengaruhi pelaksanaan pelayanan kesehatan di rumah sakit.

\section{F. Penegakan Hukum}

Penegakan hukum merupakan suatu usaha untuk mewujudkan ide-ide keadilan, kepastian hukum dan kemanfaatan sosial menjadi kenyataan. Jadi penegakan hukum pada hakikatnya adalah proses perwujudan ide-ide.

Penegakan hukum adalah proses dilakukannya upaya tegaknya atau berfungsinya norma-norma hukum secara nyata sebagai pedoman pelaku dalam lalu lintas atau hubungan-hubungan hukum dalam kehidupan bermasyarakat dan bernegara.

Penegakan hukum merupakan usaha untuk mewujudkan ide-ide dan konsepkonsep hukum yang diharapakan rakyat menjadi kenyataan. Penegakan hukum merupakan suatu proses yang melibatkan banyak hal.

Menurut Soerjono Soekanto, penegakan hukum adalah kegiatan menyerasikan hubungan nilai-nilai yang terjabarkan didalam kaidahkaidah/pandangan nilai yang mantap dan mengejewantah dan sikap tindak sebagai rangkaian penjabaran nilai tahap akhir untuk menciptakan, memelihara dan mempertahankan kedamaian pergaulan hidup.

Penegakan hukum secara konkret adalah berlakunya hukum positif dalam praktik sebagaimana seharusnya patut dipatuhi. Oleh karena itu, memberikan keadilan dalam suatu perkara berarti memutuskan hukum in concreto dalam mempertahankan dan menjamin di taatinya hukum materiil dengan menggunakan cara prosedural yang ditetapkan oleh hukum formal.

Menurut Satjipto Raharjo penegakan hukum pada hakikatnya merupakan penegakan ide-ide atau konsep-konsep tentang keadilan, kebenaran, kemamfaatan sosial, dan sebagainya. Jadi Penegakan hukum merupakan usaha untuk mewujudkan ide dan konsep-konsep tadi menjadi kenyataan.

Hakikatnya penegakan hukum mewujudkan nilai-nilai atau kaedah-kaedah yang memuat keadilan dan kebenaran, penegakan hukum bukan hanya menjadi tugas dari para penegak hukum yang sudah di kenal secara konvensional, tetapi menjadi tugas dari setiap orang. Meskipun demikian, dalam kaitannya dengan hukum publik pemerintahlah yang bertanggung jawab.

Dalam hal penegakan hukum apabila terjadi kesalahan ataupun pelanggaran, atau tidak sesuainya pelayanan kesehatan bagi pasien pengguna BPJS Kesehatan, maka pasien dapat melakukan komplain kepada pihak BPJS. Berikut adalah alur komplain ketidakpuasan pasien.

\section{Alur Komplain Pasien}

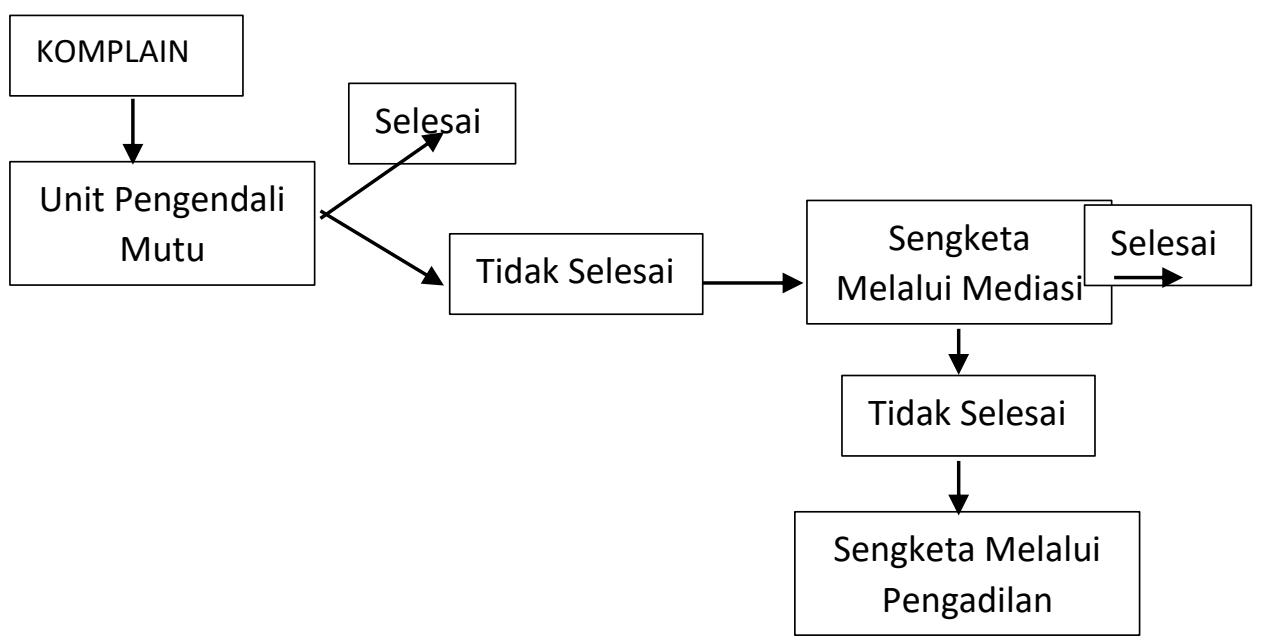


Keterangan:

1. Apabila terjadi ketidakpuasan pelayanan kesehatan maka pasien dapat mengajukan komplain kepada pihak BPJS, dan BPJS wajib menangani komplain atau aduan dari pasien paling lama 5 hari sejak diterimanya aduan;

2. Komplain tersebut ditujukan kepada bagian Unit Pengendali Mutu BPJS;

3. Apabila pihak yang merasa dirugikan yang pengaduannya belum dapat diselesaikan oleh Unit Pengendali Mutu BPJS, maka penyelesaian sengketanya dapat dilakukan melalui mekanisme mediasi (Pasal 49 UU BPJS). Mediasi tersebut dikakukan melalui bantuan mediator yang disepakati oleh kedua belah pihak (Pasal 49 Ayat (2));

4. Penyelesaian sengketa melalui mediasi ini dilakukan paling lama 30 hari kerja sejak penandatanganan kesepakatan kedua belah pihak (Pasal 49 Ayat (3)), jika penyelesaian sengketa melalui mekanisme mediasi ini sudah final atau ada kesepakatan kedua belah pihak secara tertulis maka sengketa dianggap sudah final dan selesai, namun jika belum ada kata sepakat maka penyelesaian sengketa melalui Pengadilan;

5. Dalam hal pengaduan tidak dapat diselesaikan oleh Unit Pengendali Mutu pelayanan dan penanganan pengaduan peserta melalui mekanisme mediasi tidak dapat terlaksana, maka penyelesaiannya dapat diajukan ke Pengadilan negeri wilayah tempat tinggal pemohon (Pasal 50 UU BPJS).

Hal inilah yang sampai sekarang belum diketahui oleh masyarakat, bahwa apabila dalam pelayanan kesehatan terjadi pelanggaran atau ketidakpuasan pasien maka pasien dapat mengadu kepada pihak BPJS (Dewan Pengendali Mutu). Dan apabila hal tersebut juga belum dapat menyelesaikan masalah maka pasien dapat menyelesaikan sengketa ke Pengadilan.

Dalam penyelesaian sengketa, ada juga ketentuan sanksi pidana bagi penyelenggara BPJS Kesehatan (Anggota Dewan Pengawas dan Direksi) yang terbukti melakukan pelanggaran sebagaimana telah diatur dalam Pasal 52 Undang-Undang Nomor 24 Tahun 2011 tentang BPJS maka akan di pidana dengan pidana penjara paling lama 8 (delapan) tahun dan pidana denda paling banyak $\mathrm{Rp}$. 1.000.000.000 (satu miliyar rupiah).

Tidak hanya anggota dewan pengawas dan direksi yang dapat dikenakan sanksi pidana apabila melakukan pelanggaran, tetapi pemberi kerja sebagaimana dimaksud pada Pasal 19 Undang-Undang Nomor 24 Tahun 2011 tentang BPJS juga bisa dikenakan sanksi pidana, yakni berupa pidana dengan pidana penjara paling lama 8 (delapan) tahun dan pidana denda paling banyak Rp. 1.000.000.000 (satu miliyar rupiah).

\section{KESIMPULAN}

Pelayanan kesehatan di RSUD Kertosono Kabupaten Nganjuk dikatakan sangat baik, hal tersebut dikarenakan komitmen dari RSUD Kertosono yang ingin memberikan pelayanan kesehatan sesuai dengan standar yang baik dan berdasarkan standar pelayanan publik kepada masyarakat. Akan tetapi, pada proses pembiayaan terdapat penunggakan pembayaran dari BPJS ke pihak rumah sakit. Penunggakan tersebut mencapai 6 bulan, bahkan sampai dengan dilakukannya penelitian ini tunggakan pembayaran sudah mencapai 7 bulan. Namun, meskipun terjadi penunggakan pembayaran oleh pihak BPJS, pihak RSUD tetap melayani masyarakat pasien pengguna BPJS.

Faktor pendukung dan penghambat proses pelayanan BPJS Kesehatan di RSUD Kertosono Kabupaten Nganjuk ialah yang pertama fatktor pendukung, sikap pegawai yang ramah dan sopan santun, pelayanan yang diberikan memusakan dan alur yang mudah, adanya poster 
pemberitahuan terkait dengan BPJS, tujuan dan sasaran yang jelas, dan finansial yang cukup. Sedangkan untuk faktor penghambatnya ialah banyaknya jumlah pasien yang berobat tidak sebanding dengan SDM yang dimiliki rumah sakit, sering terjadi miskomunikasi atau kesalahpahaman antara petugas dengan pasien, alat-alat medis yang belum lengkap, ketidakefisiensian proses klaim BPJS, dan yang terakhir ialah tunggakan pembayaran dari pihak BPJS. Sehingga berdasarkan hal tersbut pihakpihak yang dirugikan dapat mengajukan komplain kepada BPJS.

\section{DAFTAR PUSTAKA}

Asih, Eka Putri. 2014. Seri Buku Saku-2: Paham BPJS (Badan Penyelenggara Jaminan Sosial Kesehatan). iedrichEbert-Stiftung

Hilman Hadikusuma, 1995. Metode Pembuatan Kertas Kerja atau Skripsi Ilmu Hukum, Bandung: Mandar Maju

Iskandar, Soleh, 2016. Pelayanan kesehatan dalam Meningkatkan Kepuasan Masyarakat di Rumah Sakit Panglima Sebaya Kabupaten Paser, e-Jurnal Ilmu Pemerintahan Vol. 4 No. 2 Tahun 2016

Khairandy, Ridwan. 2011. Tanggung Jawab BPJS Ketenagakerjaan dan Asuransi Tanggung Jawab Sebagai Instrumen Perlindungan Hukum Kepada Pekerja. Jurnal Hukum Bisnis Vol 26, Jakarta

Soemitro, Rony Hanitijio. 1998. Metode Penelitian Hukum. Jakarta: Pradya Paramita.

Undang-Undang Nomor 24 Tahun 2011 tentang Badan Penyelenggaraan Jaminan Sosial 